5. Плачинда С.П. Словник давньоукраїнської міфології. Київ: Укр. письменник, 1993. $62 \mathrm{c.}$

6. Ревакович М. Крізь іншу призму: про феномен і поезію НьюЙоркської Групи. Півстоліття напівтиші: антологія поезії Нью-Йоркської Групи. Київ, 2005. 36 с.

7. Ревакович М. Нью-Йоркська група: Антологія поезії, прози та есеїстики. Львів: Піраміда. 2012. 397 с.

8. Twitchell Jeffrey, Fan Huang. Avant-Guarde Poetry in China: The Nanjing Scene 1981-1992. World Literature Today. Vol. 71. No. 1 (Winter, 1997) P. 29-35.

9. Хайдапова М.Б.-О. История формирования и развития китайской «туманной поєзии». Вестник Бурятского государственного університета. 2010. № 8. C. 123-129.

10. Хайдапова М.Б.-О. Поєтическое творчество Шу Тин в контексте развития китайской «туманной поэзии» (вторая половина 70-х - середина 80-х гг. ХХ века). Диссертация. Улан-Уде. 2011. 190 с.

11. 舒婷。舒婷的诗。出版社：人民文学出版社。2003。296 页.

DOI https://doi.org/10.30525/978-9934-26-039-1-62

\title{
ПИСЬМЕННИЦЬКИЙ ЕПІСТОЛЯРІЙ ЯК ОБ'СКТ НАУКОВИХ ДОСЛІДЖЕНЬ
}

\author{
Дузь Л. I. \\ кандидат філологічних наук, доцент, \\ доцент кафедри іноземних мов \\ Одеської національної музичної академії імені А. В. Нежданової \\ м. Одеса, Украӥна
}

Епістолярій визнано важливим видом історичних джерел, що вивчається за науковими напрямами, принципами та методами задля отримання усіх видів історичної інформації [1]. На сучасному етапі повноту дослідження закладеної у лист інформації забезпечує кросдисциплінарний дискурс, що робить епістолу об'єктом філософських, лінгвістичних, психологічних, культурологічних студій. Епістолографія стала також повновартісною галуззю сучасного літературознавства, що вивчає найважливіші особливості змісто-форми письменницьких листів [2], а також кореспонденцій особистостей, причетних до літератури та культури. У процесі конкретних історико-літературних розвідок 
уточнюються дефініції епістолографічних понять, вивчаються жанровостильові модифікації епістолярію, розробляються типології листів за різними основами [3]. Належачи до історико-культурних документів, письменницькі листи слугують джерелом суспільно-політичної, соціальної, культурної інформації.

Активізація вітчизняної літературознавчої думки протягом кінця 1990-х - початку 2000-х років пов'язана, не в останню чергу, 3 публікацією та введенням у науковий обіг невідомих письменницьких листів XIX та XX сторіч. Об'єктом наукових досліджень стали листи T. Шевченка, I. Франка, Лесі Українки, П. Куліша, В. Стефаника, В. Винниченка, Олександра Олеся, В. Стуса, багатьох інших видатних представників українського письменства.

Грунтовне дослідження вітчизняних епістолологічних праць в історичному аспекті здійснила Г. Мазоха [4]. Проаналізувавши у монографії «Український письменницький епістолярій другої половини XX століття: жанрово-стильові модифікації» праці Ф. Прокоповича, П. Гулака-Артемовського, дослідниця акцентувала на науковому вивченні епістолярного жанру у XX сторіччі та їхньому обмеженні соціологічною методологією. Науковим здобутком визнано, зокрема, комплексне дослідження листів Лесі Українки та відповідей на них, а також паралельного епістолярію, мемуарів та багатьох інших документів (В. Святовець), а також аналіз відображення у приватній кореспонденції внутрішнього, духовного життя Тараса Шевченка (Ж. Ляхова). Досягненням епістолології $є$ дослідження Ю. Шереха «Скарби, якими ми володіємо», що показує зв'язок стилю приватних письменницьких листів першої половини XIX сторіччя 3 літературними стилями доби. Можливості багатоаспектного вивчення епістолярної спадщини літераторів дають історико-літературний, текстологічний та джерелознавчий підходи до конкретного матеріалу кінця XIX - початку $\mathrm{XX}$ сторіччя (В. Дудко). Конкретні дослідження висувають проблеми методики та методології, потребують урахування компонентів історикогенетичного, порівняльно-історичного і типологічного методів [4].

Незаперечним $є$ значення письменницьких епістол як джерела біографічного матеріалу; документальність листів умотивовує їхнє вивчення у біографічному плані. Важливим є дослідження письменницьких кореспонденцій з точки зору літературного процесу з урахуванням нового погляду на участь митців слова у літературному житті епохи.

Епістолярний масив митців слова дає підстави для їхнього вивчення у плані не лише фактографічному, але й культурологічному, психологічному, естетичному. Здійснивши цілісний історико-літературний аналіз приватного листування українського письменства періоду 
1920-50-х років, В. Кузьменко показав його як специфічне явище, що виконувало особливі функції у тоталітарну добу. Науковець запропонував концепцію «поліфонічного жанрового епістолярного утворення літературного та історіографічного водночас» [2, с. 55]. Центром дослідження письменницького епістолярію стало відображення індивідуальних особливостей мислення, багатства духовного життя Івана Франка (В. Ткачівський). Новим виявився погляд на кореспонденції митців слова у книжці М. Коцюбинської «Зафіксоване й нетлінне», де лист аналізується як автопортрет із психологічними відтінками, уподобаннями, внутрішніми суперечностями митця.

Літературознавці розробляли теоретичні проблеми дослідження письменницького епістолярію, обгрунтовували завдання цілісно-системного аналізу письменницьких епістол (Ж. Ляхова, Н. Лисенко). Листи визнано джерелом пізнання особистості письменника, специфіки його творчості, його творчої індивідуальності, художнього мислення. Теза про необхідність вивчення письменницького епістолярію у психологічному плані розвиває думки про витворення у приватній кореспонденції митців портрета особистості на тлі доби і продовжує міркування про важливість дослідження на конкретному матеріалі приватного листа проблеми індивідуальності в історії культури України [5].

В центр дослідницької уваги висунуто також питання специфіки письменницького епістолярію. Грунтуючись на виробленому психологією творчості понятті індивідуальної творчої установки, Г. Мазоха дотримується думки про спільну основу художньої творчості митця та його епістолярію, яка в обох випадках «знаходить свій вияв у одній спільній формі - у художній манері письменника» [5, с. 156]. Результатом єдиного творчого процесу стає образ, у листуванні це образи автора та його адресата. Елементи художньої образності у приватній кореспонденції дають підстави дослідникам розглядати епістолярій майстрів художнього слова як літературу, - такий підхід значно розширює уявлення «про культуру слова i безпосередньо про літературу» [5, с. 156]. Трактування письменницьких листів як способу художнього самовираження, з одного боку, активізує методики, випробувані у вивченні специфіки власне художніх творів, 3 другого, - доводить потребу поєднання дослідницьких методів, зокрема, описового, структурно-семіотичного та психографічного.

Аналіз помітних досліджень письменницького епістолярію свідчить про багатоаспектність наукового дискурсу, про необхідність синтезу нових та відомих наукових методик, про залучення епістолярію як джерела фактичної, а також особистісної, психологічної, естетичної інформації про митців слова. 


\title{
Література:
}

1. Войцехівська І.Н. Епістолологія // Енциклопедія історії України: Т. 3: Е-Й / Редкол.: В. А. Смолій та ін. НАН України. Інститут історії України. - К.: Наукова думка, 2005. 672 с. / Режим доступу: http://www.history.org.ua/?termin=Epistolologiya (дата звернення: 12.02.2021)

2. Кузьменко B.I. Письменницький епістолярій в українському літературному процесі 20-50-х років XX ст. К.: Ін-т літ-ри ім. Т. Г. Шевченка, 1998. 306 с.

3. Погребняк I.В. Науково-теоретичні основи епістолярного жанру / Науковий вісник Міжнародного гуманітарного університету. Сер.: Філологія. 2017. № 28. С. 40-42.

4. Мазоха Г.С. Український письменницький епістолярій другої половини XX століття: жанрово-стильові модифікації. К.: Міленіум, 2006. $344 \mathrm{c}$.

5. Мазоха Г. С. Теоретичні аспекти дослідження письменницького епістолярію. Вісник Луганського національного університету імені Тараса Шевченка. Філологічні науки. 2013. № 2(1). С. 152-161. / Режим доступу: http://nbuv.gov.ua/UJRN/vluf_2013_2(1)_26. (Дата звернення 6.02.2021).

DOI https://doi.org/10.30525/978-9934-26-039-1-63

\section{THE INTERPRETATIONS OF THE SYMBOL OF EARTH IN POETRY BY LESYA UKRAINKA AND SARA TEASDALE}

\author{
Malitska A. D. \\ Graduate Student at the Faculty of Philology \\ Odesa I. I. Mechnikov National University \\ Odesa, Ukraine
}

Developing the new approaches to the analysis of literature is topical in modern literary studies. The modernistic poetry, for instance, is now analysed in terms of interpretation of the general cultural symbols that function in it. The natural element of earth as a symbol is one of the oldest and most widespread in the world literature. In the Neo-Romanticism, its abilities to be interpreted expand. Earth is one of the crucial symbols in the poetry of Ukrainian poet Lesya Ukrainka and American poet Sara Teasdale. In our 